\title{
Mapping Research on European VET Policy With a Systematic Literature Review Method: A Pilot Study
}

\author{
Ianina Scheuch*, Sandra Bohlinger, Anne Bieß, Hoang Long Nguyen \\ TU Dresden, Institute of Vocational Education and Vocational Didactics, Chair of Adult \\ Education / Continuing Vocational Education and Training and Comparative Education, \\ Helmholtzstr. 10, 01069 Dresden, Germany
}

Received: 22 December 2020, Accepted: 30 September 2021

\begin{abstract}
Purpose: A systematic literature review has neglected for years in both national and international vocational educational and training (VET) policy research. Recently, scholarly interest in and the need for such a review has increased rapidly. This review introduces the application of the systematic literature review method, with a focus on research work completed in European VET policy.
\end{abstract}

Approach: To investigate the value and applicability of the systematic literature review method in European VET policy research, we conducted a pilot study following the guidelines and procedures presented by Gessler and Siemer.

Findings: First, the process of conducting a literature review and its major methodological steps are described, followed by a descriptive analysis of the sample and characteristics of the studies reviewed. Second, initial insights into the research methodology and the topics that emerged during its application are presented. Altogether, we documented a first attempt to systematize research on European VET policy, including lessons learned from conducting a systematic literature review.

Conclusion: The review revealed that although research on international European VET policy research has increased in recent years, hardly any systematization of the current

*Corresponding author: ianina.scheuch@tu-dresden.de 
research has been proposed. Instead, most research has been limited to identifying specific country-related factors. By comparison, we propose a systematic approach to reviewing research on European VET policy, being well aware of the strengths and limitations of the proposed method and the results. Thus, this systematic review presents a substantial starting point and research agenda for further studies on this topic.

Keywords: Systematic Literature Review, Education Policy, Europe, VET, Pilot Study, Vocational Education and Training

\section{Introduction}

In recent decades, VET policy and governance have attracted growing interest in international and comparative studies, such as country case studies or cross-national comparisons. Some studies have addressed the internationalization of VET (Smith \& Smith, 1999; Tran, 2013), whereas others have examined the international transfer of VET (Euler, 2013; Mewaldt, 2014). Further, some studies have focused on VET in Europe in general (e.g., with country reports provided by the Cedefop), with many of these addressing VET policy in relation to the Lisbon strategy (Ante, 2016; Walkenhorst, 2005). Some review articles have emerged in the past years, indicating a highly complex and fragmented field (Busemeyer \& Trampusch, 2011; Li \& Pilz, 2021). Although these studies have provided a partial overview of the field, it remains somewhat vague how such literature reviews were conducted methodologically. Thus, despite mounting research on education policy (Bohlinger et al., 2016; Busemeyer \& Trampusch, 2011) and attempts to systematize methodological and theoretical approaches to investigating governance and policy transfer in VET (Barabasch, 2010; Li \& Pilz, 2021), few studies have examined the current state of research in the field by conducting systematic literature reviews (see for example, Caves et al., 2019).

Against a backdrop of the vast volume of literature, the aim of our pilot study was to apply a systematic literature review method in the field of international (in detail: European) VET research. We explored whether and subsequently how the method could be used to map the current state of research. To investigate the value and applicability of the systematic literature review in examining such research, we performed the methodological steps proposed by Gessler and Siemer (2020). In particular, we were concerned with reporting the process of applying a systematic literature review to research addressing European VET policy and assessing its practicability. To that end, we focused on the methods used and their applicability, not on expanding the discourse on VET policy in Europe. The remainder of this paper proceeds as follows: First, we present the methods used in this study. Second, we report our pilot findings and explain the limitations of our review. Finally, we articulate the implications for future research. 


\section{Methodology}

The pilot study was undertaken as a systematic literature review using the methodology proposed by Gessler and Siemer (2020). Inspired by systematic reviews in other fields (e.g., medicine), this approach allows other researchers to replicate and update the literature by providing a transparent account of the reviewers' procedures (Booth, 2016; Hart, 2018; Moher et al., 2009). In accordance with Gessler and Siemer (2020, p. 104; see Table 4), the procedure of a literature review consists of the following four steps (Figure 1):

1. Defining the scope (i.e., specifying the research problem and research question).

2. Selecting data (systematic search and eligibility screening: Defining the sources and search terms, including the relevant research, and screening and reading the selected research to exclude ineligible research).

3. Processing the data, involving critical appraisal (i.e., assessing the quality of the selected sources to exclude poor or inappropriate ones), analysis (i.e., selecting the relevant data from the different texts and critically evaluating the data extracted), and synthesis (i.e., synthesizing and reanalyzing the pooled data).

4. Reporting the data (presenting the findings and discussing the conclusions and limitations of the review).

We used four steps of the review process to create a review protocol to conduct the pilot study. In the following steps, we provide insights into our pilot results by reflecting on the application and suitability of the literature review method in our specific topic area.

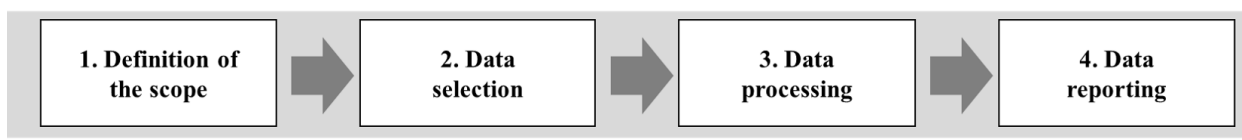

Figure 1: Steps of a Systematic Literature Review (adapted from Gessler and Siemer, 2020) 


\subsection{Step 1: Defining the Scope}

The pilot study focused on the European VET policy and aimed to identify relevant literature following a clear, sound methodological approach proposed by Gessler and Siemer (2020). Our aim was not to detail research on European VET policy in terms of comparative education. However, this study provides an additional step in mapping the landscape and scope of research on European VET policy research, while applying and testing the methodology in a heterogeneous field. In particular, we sought to answer the following research questions:

1. What literature can be identified by applying a systematic literature review method of research on European VET policy?

2. What are the main characteristics of the identified studies?

3. Which research methodologies were followed in the selected studies?

4. Which research topics can be identified from the studies?

5. What are the strengths and limitations of the systematic literature review method applied to research on European VET policies?

\subsection{Step 2: Selecting the Data}

The literature search for the review, conducted from August to November 2020, involved searching databases for relevant studies in peer-reviewed literature. We selected the following databases: Academic Source Complete (EBSCO), Web of Science (WoS), VOCEDplus, ERIC, and Scopus (all databases frequently used by researchers across various disciplines and mentioned by Gessler \& Siemer, 2020). To search titles, abstracts, and keywords, we developed a search query by breaking the main topic down into search terms. We searched for "VET" or "vocational education and training"1 in combination with "polic $c^{\star "}$ (and other appropriate terms, e.g., "governance" or "system*", and "reform*"). We limited our search to English peerreviewed academic articles published from 2000 to 2020, being aware that there might be numerous non-English articles. ${ }^{2}$ We also restricted the document type to "journal articles" and used only sources that were available in full text. In doing so, we attempted only a pilot

1 In Europe, the common term for skills development in institutionalized pathways refers to "vocational education and training" (VET). We are well aware that terms such as "industrial training", "work-based-learning", and "apprenticeship" are common in other contexts. However, as our focus is on policy and governance in vocational contexts in Europe, our main search focused on the terms "vocational education and training" either in combination or as single terms.

2 Our first attempt at the systematic literature review aimed at identifying meta-studies (meta-analyses), which presumably would have been in English only. However, because we could not identify any meta-studies addressing European VET policy or VET policy per se, we expanded our scope towards non-meta-studies but kept English as the sole language of publication. 
search of the literature (i.e., limited to most representative articles in peer-reviewed journals), not a comprehensive literature selection.

Figure 2 represents the stages of selecting sources from the literature. First, the titles, abstracts, and keywords of the journal articles were scanned for any connection to our chief topic. All articles related to other fields (e.g., veterinarian research) were excluded. Of the remaining 75 articles, five duplicate articles (i.e., the same article indexed in different databases) were eliminated. After this initial check, we assessed the remaining articles in two stages. The first stage involved evaluating the abstracts based on predefined criteria. One author marked the articles of exclusion based on the criteria, which were double-checked by another author. Accordingly, 28 of the 70 articles were excluded. The second stage comprised evaluating the relevance of the full-text articles. Ultimately, 30 articles remained for further investigation.

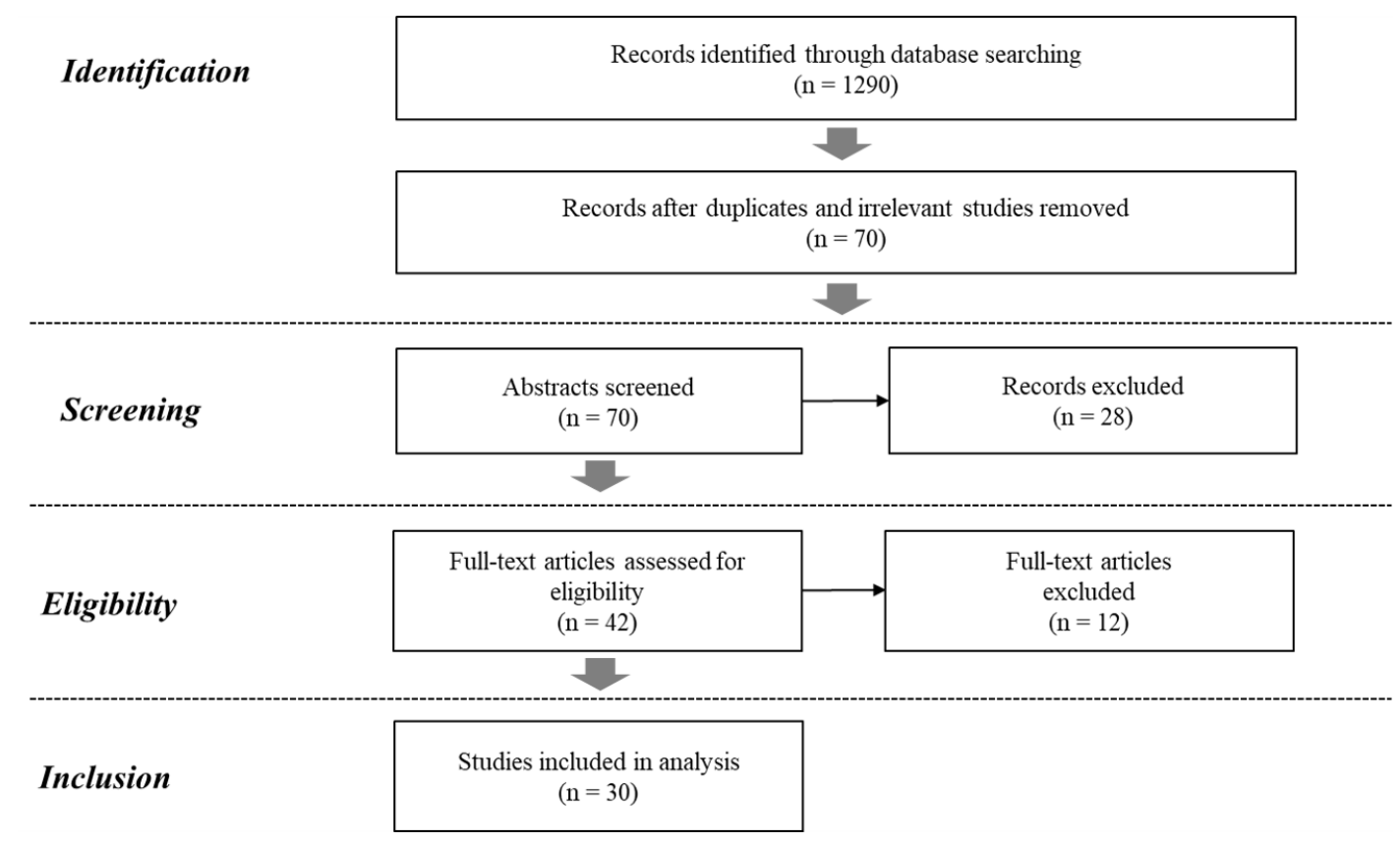

Figure 2: Flow Diagram of Article Selection

To be included in the review (i.e., pilot study), the articles had to fulfill four criteria:

1. Focus on research addressing the VET policy. Because we aimed at a comprehensive understanding of the topic, we did not exclude any research context and consciously included all kinds of articles, regardless of their disciplinary perspective. 
2. Provide insights into the European context at national, international, and/or systemic levels.

3. Include a clear description of the theoretical approach taken, or the methodology in the case of empirical studies.

4. Be published in English in (double-blind) peer-reviewed journal articles from 2000 (i.e., commencing with the Lisbon Strategy) to 2020.

\subsection{Step 3: Processing the Data}

The third step included critical appraisal, extracting relevant data, data analysis, and synthesis. After identifying our main sources, selected articles were evaluated based on predefined criteria $^{3}$ by two authors separately. Their individual results were discussed and agreed upon. Subsequently, a data extraction form was developed to process the data. To characterize the literature examined in our pilot review, chief characteristics were extracted from each study (i.e., authors, source, date of publication, and first author's country of residence), the study was summarized and research questions were noted. To analyze the articles, we first structured and classified them based on evident data (e.g., date of publication or journal background) and assessed their overall relevance in Microsoft Excel. Based on our research questions, we developed an overview of the themes emerging from the articles. For this purpose, we analyzed the content based on their similarities and differences (Aveyard, 2010) on a broader level and grouped similar themes into main categories. After that, we developed a brief summary of the aim, approach, and major findings of each article and wrote a short statement on the findings. Finally, we undertook a critical discussion and systematization of the emerging themes.

\subsection{Step 4: Reporting the Data}

In the final step, a descriptive analysis of the sample and the characteristics of the articles were reported. To characterize the literature included in our review, we used six categories: (1) Date of publication, (2) first author's country of residence, (3) journals and subject area, (4) type of articles and research methods, and (5) emerging topics and systematization of content. Given that our study was a pilot study, we focused on the application of the method and the reporting of the data, rather than the interpretation of data.

3 Critical appraisal tools are available for many kinds of research studies (see Gessler \& Siemer, 2020). For the purpose of our pilot study, we only focused on our predefined selection criteria. 


\section{Results}

\subsection{Date of Publication}

Articles published between 2004 and 2020 are depicted in Figure 3. The majority of them were published after 2010, with the highest number of sources found in 2010 (four articles), 2015 (four articles), and reached a peak in 2018 (five articles). The trend line and constant presence of publications in the last five years indicated that the publication of articles is increasing. This emphasized the issue and the nature of the debate about adapting to changing environments, implying growing interest in scientific research and publishing in peerreviewed journals. This supported the findings of the European VET policy becoming the focus of researchers, particularly after 2000, perhaps being influenced by developments in EU policy (Lisbon Strategy, Europe 2020). As earlier research on European VET policy focused primarily on these developments from a broader perspective over the years, the focus shifted towards the question of how VET is governed at supranational and national levels.

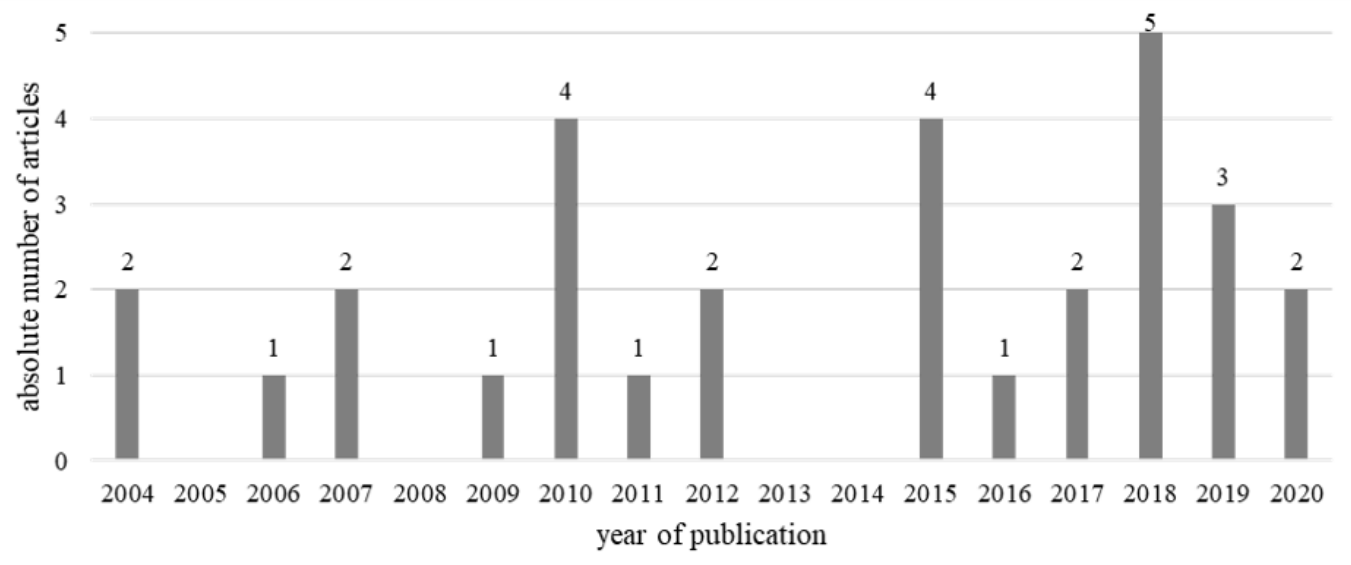

Figure 3: Number of Articles by Year of Publication

\subsection{Country of Residence of First Author}

In this classification, we examined the background of each first author to provide more insights into their country of residence. As can be observed in Figure 4, nine articles originated in Germany, followed by four articles produced in the UK. Studies were located from Estonia, Switzerland, Italy, and Norway. Numerous contributions from Germany can be explained by both the relatively high number of researchers in the field emanating from Germany's 
high number of inhabitants and an extensive national research interest in VET. Since we only focused on articles published exclusively in English, the data also illustrated countries current general interest to publish in English. However, this classification did not provide an explicable finding, since the origin of a study can be attributed to the increasing international cooperation of universities and research institutions. Most of the studies were written by a single author, with few studies produced in cooperation with other scholars.

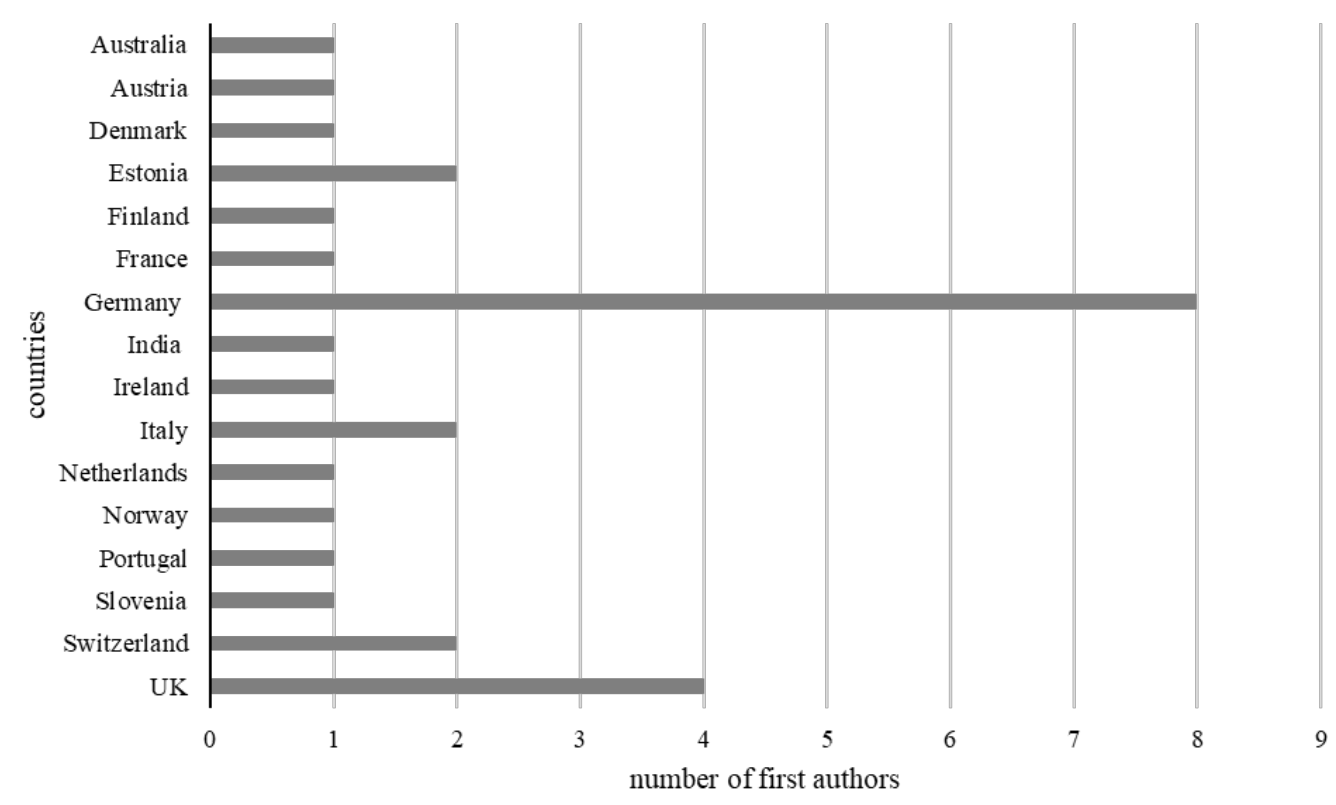

Figure 4: Country of Residence of First Author

\subsection{Journals and Subject Areas}

By limiting the articles to only double-blind peer-reviewed journals, we were able to determine the most important current journals in this area. The publications were classified by being divided into two groups: Educational and policy-related journals. Twenty-seven sources were published in leading educational journals with a clear focus on VET. However, as exhibited in Table 1, three articles were published in policy-related journals. The journals Research in Comparative and International Education (RCIE), International Journal for Vocational Education and Training (IJRVET), and Journal of Vocational Education and Training (JVET) were well represented with between four and six articles. European Journal of Vocational Training (EJVT), European Journal of Education (EJE), and Journal of Education and Work (JEW), with a European focus were also well represented with two to three articles. The remaining 
journals were represented by only one article each. The high distribution in different journals can be explained by the fact that VET is a highly heterogeneous field and has been researched by various disciplines with theoretical and empirical approaches.

Table 1: Journals and Subject Areas

\begin{tabular}{|c|c|c|}
\hline Journal (educational focus, VET) & Abbreviation & \# \\
\hline Research in Comparative and International Education & RCIE & 6 \\
\hline International Journal for Vocational Education and Training & IJVETR & 5 \\
\hline Journal of Vocational Education and Training & JVET & 4 \\
\hline European Journal of Vocational Training & EJVT & 3 \\
\hline European Journal of Education & EJE & 2 \\
\hline Journal of Education and Work & JEW & 2 \\
\hline Journal of Adult and Continuing Education & JACE & 1 \\
\hline Empirical Research in Vocational Education and Training & ERVET & 1 \\
\hline International Journal of Lifelong Education & IJLE & 1 \\
\hline Journal of Comparative and International Education & Compare & 1 \\
\hline Oxford Review of Education & Oxf. Rev. Educ. & 1 \\
\hline $\mathbf{N}($ total $)$ & & 27 \\
\hline Journal (policy-related focus, others) & Abbreviation & \# \\
\hline Governance: An International Journal of Policy and Administration & Governance & 1 \\
\hline European Journal of Industrial Relations & Eur. J. Ind. Relat. & 1 \\
\hline Transfer: The European Review of Labour and Research & Transfer & 1 \\
\hline $\mathbf{N}($ total) & & 3 \\
\hline
\end{tabular}

\subsection{Types of Articles and Research Methods}

Another classification of articles was provided based on the type of article and the research methodology used. The articles were first categorized into applied research articles and theoretical articles to examine whether the articles were either conceptual or empirical in nature. For some articles, the author did not state which method was applied. These characteristics were assessed after reading the articles. Articles were classified as theoretical papers if there was a limited or absent empirical component. If a clearly elaborated methodological and empirical component existed, the article was classified as empirical research. Overall, the majority of articles were empirical in nature, with less research providing only a theoretical (conceptual) analysis.

A close examination of the methodology of the articles revealed that the majority were qualitative or explorative in nature, with a mix of qualitative and quantitative methods. Almost half of the articles involved single-or multiple-case studies. The preferred methods for collecting data were interviews and questionnaires. Other forms included the analysis of 
political documents and other historical or national data. Common data analysis methods involved content analysis or country-based analysis. This wide range of research approaches and methods emphasizes the growing interest of researchers from different backgrounds and perspectives.

\subsection{Emerging Topics and Systematizing the Content}

Following the planned steps, the articles were classified by assessing the similarities of topics and methods used. In the first preliminary analysis, we identified three main categories (or primary topics): EU policy and EU governance, comparison of countries, and impact of policy on Member States-and three methodological instruments-content analysis, comparative analysis of countries, and single-country studies (Figure 5). Although they overlap in scope and content, they provided initial insights into the content and state of research on the topic. Due to wide ranging topics that emerged in the pilot study, we briefly summarized the articles in each category.

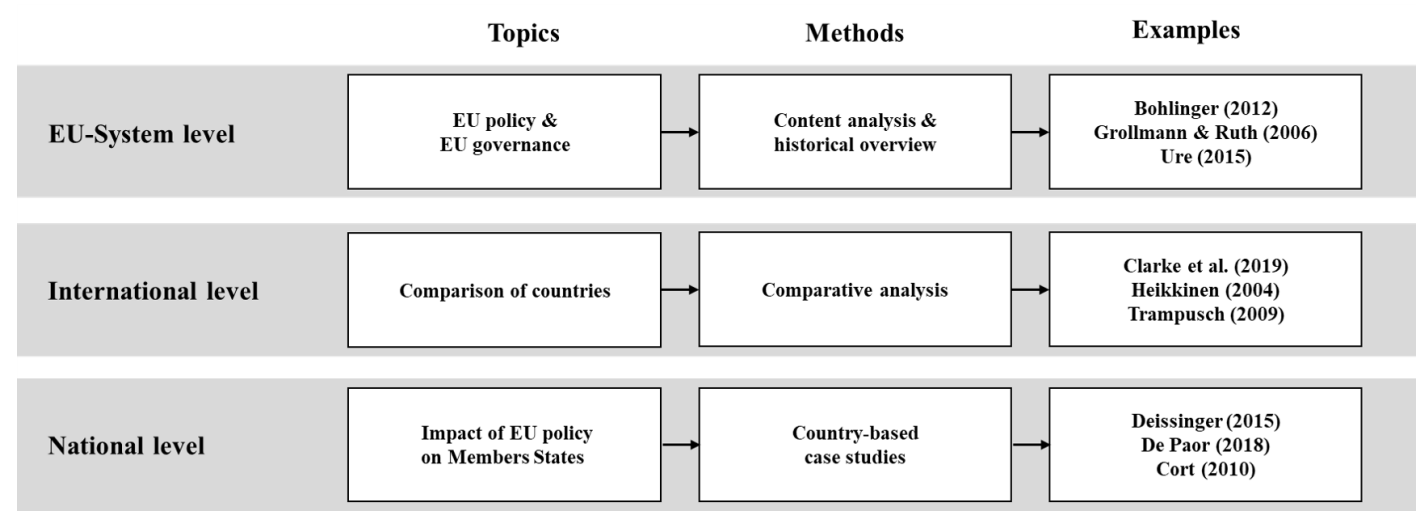

Figure 5: Emerging Topics and Systematization of Content

\section{(1) Governance in European VET Policy at the EU System Level}

Regarding content, 12 articles were assigned to the first category. The topic of EU policy or governance in VET was examined at the European meta or macro level. At this level, the specifications and implementation of VET policies in Europe were analyzed. Contextually, the question of the success of established governance structures and processes was relevant, being measured by the outcomes and structures of VET systems and their functionality (Barabasch, 2010). We found diverse article topics such as implementation of qualifications frameworks, VET policies and governance structures, comparisons of training models, and 
more. The methodological approach of these articles employed content analysis, historical overviews, and qualitative analysis of relevant documents.

Specifically, Bohlinger (2012) and Ure (2015) analyzed countries' experiences with learning outcomes and its efforts to establish or reform qualifications frameworks according to the European Qualifications Framework (EQF). We revealed the emergence of a learning outcomes orientation from an EU policy perspective and reviewed countries' anticipations and expectations regarding the development of qualifications frameworks and instruments to validate learning outcomes. The focus of both papers is on governing VET policy, for example, by means of the Open Method of Coordination (OMC). Similarly, Grollmann and Ruth (2006) address the Lisbon Agenda and its implications for VET. Their article covers the relevant EU policy topics, including the Bruges-Copenhagen Process, the ECVET (European Credit System for Vocational Education and Training), the EQF, and the OMC as a means to attain the Lisbon Goals. The authors showed that there was "no standard European path for achieving the Lisbon Goals, but rather that there are considerable variations depending on the prevailing VET systems and the respective VET policy" (Grollmann \& Ruth, 2006, p. 366). From the aforementioned EU policy topics, the ECVET is dealt with in greater depth in another paper. Ryan et al. (2018) focused on the equivalency and compatibility between the ECVET and the ECTS (European Credit Transfer System) by reviewing the findings of 11 EU-funded projects. The authors concluded that the projects were successful in identifying several points of compatibility and developing useful tools and frameworks to facilitate permeability between the two systems. While achieving credit equivalency between the ECVET and the ECTS does not seem feasible, the findings indicated that using a learning outcomebased equivalency framework seems a more promising approach.

Greinert (2004) and Clarke and Winch (2015) analyzed "design philosophies" (Clarke \& Winch, 2015, p. 543) of VET policies and VET structures. The authors identified and compared national VET structures and training models (mostly the German apprenticeship scheme and the Anglo-Saxon training model) against other countries' VET structures in light of their historical emergence. Contrary to the EU's dominating VET policy aims, they conclude that "the effectiveness of the European tools and their successful implementation at occupational and sectoral levels [...] will rest on incorporating employee interests and greater educational content into VET systems" (Clarke \& Winch, 2015, p. 604). Similarly, but with a stronger focus on decision-making processes, Oliver (2010) applies a framework of governance (Pierre \& Peter, 2005) "to assess the impact of complexity in VET governance systems by focusing on how complexity affects the four governance system outcomes: Adaptability, coherence, inclusiveness, and accountability" of VET systems in England, Australia, the United States, Germany, Spain, and Denmark (Oliver, 2010, p. 270). While Greinert (2004) and Clarke and Winch (2015) contrast mostly different training models, Emmenegger et al. (2019) compare similar training models-so-called collective skill formation systems in 
Austria, Denmark, Germany, the Netherlands, and Switzerland. Their conceptual article focuses on corporative and decentralized governance structures where the authors develop a "framework for the analysis of cooperation in decentralised collective skill formation systems" (Emmenegger et al., 2019, p. 23) that is "helpful for the analysis of those areas of political economies in which actors face cooperation dilemmas within decentralised governance contexts" (p. 39). Cooperation as a condition of success is also emphasized in an article by Šćepanović and Artiles (2020). The concept of dual VET is discussed by explaining the competing logics behind it and providing an overview of the EU's policy approaches to VET. They claim that VET represents a special kind of formation, which requires high levels of coordination among all stakeholders to ensure quality and comparability. However, many European countries lack necessary institutional prerequisites. Consequently, "despite the investment of significant resources into the promotion of 'dual' VET, the results so far have been, and are likely to remain, highly uneven" (Šćepanović \& Artiles, 2020, p. 24).

Rauner and Wittig (2010) also compared corporativist VET systems and structures in Austria, Denmark, Germany, and Switzerland. Similar to Greinert, they focus on the incorporation of work process knowledge in VET structures and its implications for governing VET structures. Their overview of a theoretical framework to identify plural governance structures in VET (in particular in apprenticeship schemes) concludes that "complexity associated with different governance processes and the ways they have evolved demonstrates a need to distinguish between complexity relating to decision-making processes and policy instruments and processes for allocating resources and generating feedback" (Rauner \& Wittig, 2010, p. 271).

Viertel (2010) explored international VET cooperation and made the case for considering sustainable development to be a policy obligation for the European Training Foundation (ETF) and VET reform efforts in its partner countries as "adjusting VET to today's complex sustainability challenges is a major, but essential task" (Viertel, 2010, p. 231). Based on a discussion of economic practices from a sustainability perspective, the author investigated what impact on knowledge and skills could be derived from this. Implications for VET reforms, especially those supported by the ETF, include the application of inclusive practices, the reconsideration of competences for sustainable development, and the design of appropriate didactical approaches to foster them.

The article by Kämäräinen (2017) is somewhat different from the other articles in that it is a tribute to David Raffe's lifetime achievement on VET research, VET policy, and European cooperation. 


\section{(2) European VET Policy and Cross-Country Comparisons in the EU}

The second category examines the European VET policy and comprises cross-country comparisons. Ten articles were identified in this category, which were heterogeneous regarding content. There were articles that provided general insight into recent developments in VET policy in the EU, presenting problems and challenges using country-specific examples. Further, other articles explored cross-national variations with formally institutionalized "feedback mechanisms". There was also often a sector-specific focus, such as a study on VET in the construction sector comparing several European countries. Other articles focused on national VET systems, their structures, coherence, and educational reforms in specific European countries. Although the contents of this category differed greatly, their methodological approaches were similar and mostly employed comparative analyses.

Trampusch (2009) and Souto-Otero and Ure (2012) focused on a system-related perspective exploring how European VET policies were reflected in different national VET systems. The authors compared two countries based on a case study analysis. Trampusch (2009) analyzed the effects of the Copenhagen process on vocational training policy in Austria and Germany. Embedding the analysis of Europeanization in a more general analysis of institutional change and building upon a comparison of Germany and Austria, the author offered insights into two divergent dynamics of Europeanization in two similar VET systems. In Germany, Europeanization occurs as reform policies and politics. However, in Austria, Europeanization occurs more as institutional change by default, without strategically enacted reform initiatives shaped by the EU. Similarly, based on a two-country comparison, SoutoOtero and Ure (2012) explored differences in governmental ambition in Norway and Spain to increase coherence, defined as "the internal connections of individual educational strands and the points of contact between strands," (Souto-Otero \& Ure, 2012, p. 92) of their VET systems. The authors provide two conceptualizations of coherence (vertical and horizontal coherence) and illustrated that while both countries sought coherence, the roots of their striving for it, the ways that they operationalized the term, and the emphasis of their actions differed substantially. This can be related to how VET interests and stakeholders are organized in each country. In comparison, Heikkinen (2004) determined the need to use a historical and contextual approach to understanding VET systems through discussions on continuing education in Nordic countries and Germany.

Following a comparative perspective, other studies focused on the investigation of the European VET policy convergence through specific elements, tools, and topics, e.g., "modularisation" and "formal feedback mechanisms". In a cross-country comparison, Pilz et al. (2018) compared the experiences of modularization in seven European countries. The authors described different pathways and indicated that while modularization in some countries takes a radical form, other countries follow a mixed approach. The authors concluded that no two countries have adopted the same form of modularization, yet some countries 
have cited common challenges in the modularization process. Similarly, Markowitsch and Hefler (2018) addressed the topic of feedback-mechanism building through a comparative analysis of 15 European countries to enhance an understanding of cross-national variations in formally institutionalized "feedback mechanisms" between VET and the labor market. The study identified four different formal feedback mechanisms that represented the main types found in European countries: 1) The liberal model, explained by VET in England and higher VET in Austria; 2) the statist model, explained by school-based VET in Austria; 3) the participatory model, explained by VET in France; and 4) the coordinated model, explained by apprenticeship training in Germany and Austria. Other authors attended to different patterns of social dialogue over VET and their implications for qualifications and workforce mobility. For Winterton (2007), qualification and related processes played different roles and were given different degrees of attention in the agendas of social partners across countries, depending on the model of social partnership. For example, state-regulated systems (such as Germany and France) facilitate a clearly prescribed role for social partners, whereas market systems (such as Italy and the UK) are associated with uneven involvement. Social dialogue in school-focused systems (e.g., Italy and France) is inevitably less developed than in workplace-focused systems (e.g., Germany and the UK) because schooled VET is divorced from the domain where the social partners have the most competence.

Further, there were articles examining specific occupational foci or providing insights from micro-level perspectives. Clarke et al. (2020) drew on a study of VET regarding lowenergy construction (LEC) developments in 10 countries (Belgium, Bulgaria, Finland, Germany, Hungary, Ireland, Italy, Poland, Slovenia, and Spain), which analyzed current provisions in the context of near-zero energy building (NZEB) implementation, the construction labor market, workforce characteristics, and national VET systems. Roosmaa (2019) analyzed how the choice of upper-secondary education and training specialization, general or vocational, enabled future participation in non-formal education (NFE) based on EU Labour Force Survey data from 28 countries. Misra (2011) shed light on VET teacher training systems across European countries by offering insights into policies and approaches adopted in the EU to train VET teachers. Drawing on results from document analyses and interviews (e.g., with VET teachers, representatives from VET teacher unions, and VET policy makers at the government level), the author identified core VET teacher training challenges in Europe and recommended several strategies for the continuing professionalization of VET teachers.

Although most studies focused on the differences between the countries concerned and the EU Member States, some scholars provided insights into the integration and implementation of the Lisbon Strategy and differences between the partner countries ${ }^{4}$. For example, Masson (2007) provided an overview of recent developments and challenges faced by VET

4 The term "partner countries" refers to the use of the word in the context of the article. The term is not to be equated with the European Member States, it refers to the partner countries of the European Training Foundation (ETF) such as Serbia, Romania, Turkey, Tunisia, Hungary etc. (see Masson, 2007, p. 48f.). 
systems in the Western Balkans, Turkey, and other countries covered by the "wider European neighborhood" policy. This results in diverse situations across the Union and new Member States and is even greater in partner countries. The results also establish that the messages from Copenhagen have already begun to take hold in some of these countries. Their systemic value has increased awareness and acted as a catalyst for reform.

\section{(3) European VET Policy Implementation at the National Levels}

Of the 30 identified articles, eight could be assigned to the third main category. A common theme of all articles in this category was the tracing of the Europeanization processes of VET systems. In this context, the impact of the European VET policy on specific education policy mechanisms or effects on the VET or education systems of specific national Member States were investigated. Thus, these studies examined the effects of the EU VET policy (decisions, directives, recommendations, etc.) on Member States and were conducted as country studies or case studies. Due to the consideration of such processes at a specific country level, only a limited summarizing consideration of the contents of the articles was feasible.

Some articles dealt with the impact of education policy processes at a supranational level (EU level), such as the Lisbon Strategy and the Copenhagen Process, to a national level. For example, Cort (2010) examined the interactions between the Copenhagen Process, European VET, and Danish VET policies. Based on analyses of policy documents, research reports, and social actor-level interviews, Cort highlighted institutional changes in VET. Consequently, she drew conclusions about potential changes that need long term consideration. In examining the impact of European policy processes, other articles addressed policy instruments in particular and their application in specific European Member States.

Deissinger (2015) focused on the institutional field of vocational education. Regarding the effects of the alignment of national VET systems, he analyzed supranational governance instruments in the context of the EQF. Using Germany as an example, he examined the forms and practices of nongovernmental institutions in the vocational education system and drew conclusions about their responsibility for preserving the culture of the dual system.

De Paor (2018) used the results of an explanatory case study in the context of the outcomes of Erasmus+ and the strategic partnership with QUAKE to examine the role of the professional development of teachers in VET. The findings, drawn from the views of Irish VET teachers, demonstrated the importance of the use of European tools such as ECVET in teachers' professional development, which can facilitate making professional development an integral part of the teaching and learning process, ensuring more successful adoption of educational change.

The effects of the Bologna Process on the Dutch dual higher education system were the focus of van Houten (2018). His analysis focused on the effects on employment opportunities in the labor market. In this context, it highlights opportunities and tensions in employment 
relationships for students and employers. Through his findings, van Houten uncovered a gap between higher vocational education and secondary vocational education, which reduced the employability of low-skilled workers and contributed to the inequality of employment opportunities for vocational graduates.

Two of the articles dealt with the impact of European professional policy on professionalization processes of the heterogeneous professional group of adult educators and the standardization of the recognition of competences in this field. Mikulec (2019) analyzed the formulation of requirements for adult education by the European Union and examined their impact on Slovenian adult education. Within the framework of a document analysis, efforts to conceptualize the recognition processes of adult educators' professional competences in Slovenia were traced. He found that unified recognition processes were unlikely due to the unmanageable heterogeneity of professional roles and competences to be recognized. Paulos (2015) focused on the EU's contribution to the definition of adult education policy at a country level. Using the example of education policy structures in Portugal, the author explained that the professionalization of adult educators in Portugal was in a process of alignment. A need for evidence-based policies to create structures for the professional development of adult educators was identified.

Rein (2017) also dealt with competence recognition. His research related to the increasing science-related demand for company specialists and managers and the resulting design of the professionalization of these professions. By examining learning outcomes in dual vocational study programs in Germany, he found characteristics of overarching vocational competencies and defined relevant requirement areas in initial and continuing education and training. These are seen as important prerequisites for enabling the connectivity of qualifications and transitions within and between education systems.

Loogma (2016) dealt with educational policy mechanisms in general. This author explored the process of Europeanization of the VET policy in terms of policy learning and policy transfer in general. To make the implementation of these processes transparent, she examined the process of redesigning an educational space through the influences of Europeanization of VET policy, using Estonia as an example. In this case study, the increase in the implementation of VET institutions, the shift toward active learning by the EU, and the introduction of standardized policy instruments were made evident.

\subsection{Limitations of the Systematization of the Content}

We are aware that the three main categories presented above overlap somewhat with one another and with other topics identified in the sample. For that reason, the basic purpose of any literature review - that is, to compare contexts and provide a mapping of existing knowledge in a field—could be fulfilled only to a limited extent. In particular, some core topics adjacent 
to the three main categories were European tools, policies, and instruments to govern VET, the professionalization of VET staff (teacher training, adult educators), and models and structures of VET (i.e., VET regimes). Other articles covered topics such as the modularization of VET or the Bologna process in higher education. At the same time, our analysis revealed no overarching (theoretical) framework or academic discipline upon which the articles had been built. Research in the field refers to various (educational) political contexts, contains reform strategies, and, in some cases, follows different methodological logics. Because the methodological approaches to research in the field exhibit fragmentation, any systematic literature review of this field would be characterized by certain challenges and may be regarded as an additional step in accessing and systematizing such a complex research topic.

\section{Discussion and Conclusion}

Research on European VET policy can be described as a highly heterogeneous field that challenges systematic investigations in the literature. In our pilot study, we found that the systematic literature review method was difficult to apply given numerous limitations and restrictions, which will be discussed critically and considered for future research in this field. In this section, we review our experience with the process of conducting a systematic review. We structured our discussion according to the four-step model as introduced in Section 2. Although more research is required, we highlight some lessons learned from our pilot study.

First, any systematic literature review should begin with a number of research questions and a clear scope. In the fragmented, heterogeneous field of European VET policy, research questions for systematic literature reviews should seek to help synthesize current knowledge and offer a state-of-the-art overview of research in the field. However, overly broad research questions can result in massive amounts of information, thereby making literature reviews unmanageable. Consequently, narrowing the scope of research and focusing on a subtopic or more specific research questions in the area of interest could be helpful (see for example, Caves et al., 2019). Beyond that, a type of review (e.g., narrative review, scoping review, metaanalyses) suitable to the scope should be chosen (e.g., Gessler \& Siemer, 2020).

Second, data selection is a critical step for any systematic review, and our attempts to follow the process of a systematic literature review have highlighted several domain-specific challenges in data selection. Within the scope of our pilot study, we searched certain databases and focused only on double-blind peer-reviewed English journal articles. Our search was also restricted to a span of 20 years, and as a result, the search results were limited. Grey literature (e.g., working papers and conference presentations), which often provide new and current scientific findings (in this particular field), was not integrated into our review. Moreover, we excluded monographies, anthologies, and political documents, such as directives, recommendations, or guidelines, which are indispensable sources in the field. Based 
on our pilot study, only a few articles covered a 20-year period of research. Moreover, some relevant research articles were clearly missing from our sample, although we are aware that such literature exists (e.g., Bohlinger, 2019; Brockmann et al., 2009). Our oversight can be explained by our selection criteria, which were highly restrictive. Combinations of search terms such as "VET" and "policy", "VET" and "governance", "VET" and "system" may have netted some of the more obvious titles in literature in the field. Unfortunately, a great deal was also excluded, such as articles on VET policy that do not contain the term "VET" or have titles where VET is paired with a relevant term (e.g., "competence"). Future research should focus on the selection of keywords and the overall search strategy. The selection of keywords should be derived from the research questions obtained from known primary studies and cross-checked in terms of terminology and cultural differences in cross-country studies. Depending on the purpose of the review, the search can be more comprehensive (scoping review) or selective (i.e., meta-analysis). For a comprehensive stand-alone literature review, the literature search should include multiple databases, be conducted with backward and forward searches, and include additional relevant literature indicated by snowballing or experts in the field, among other strategies.

Third, data processing needs to be extracted and synthesized in an accurate manner, suitable for the research questions. While our sample was small and extremely diverse in scope, it did not reflect the importance of the topic or the relevance of some literature in the field. For example, we decided against ranking the final list of articles according to their $\mathrm{H}$-factor or the number of citations in Google Scholar. Moreover, as we excluded articles by international stakeholders such as the OECD or the European Commission, we are unable to derive any statement about the importance of the articles in our sample. Our general data extraction was an essential, helpful step to deconstruct the range of studies and facilitate their comparison. The central result of the application of the literature review method is that EU VET policy research is a heterogeneous field concerning academic disciplines, theories, and research approaches. As Barabasch and Wolf (2009) concluded in their study on policy transfer in VET, methodological research on European VET policy is equivalent to an investigative research approach because receiving access to information sources and background information is demanding. Furthermore, the interests of the individual countries in education policy are highly diverse; hence, political discourse can hardly be depicted in its entirety (e.g., Barabasch \& Wolf, 2009, p. 23). Due to the inter- and transdisciplinary nature of our sample, the results of our analysis are more general, and we have only been able to provide a descriptive systematization in the field. Although we did not perform a detailed content analysis, our work marks a starting point for future research on this topic. Even Gessler and Siemer (2020) have underscored the importance of more quantitative reviews, and to be appropriate for statistical meta-analysis, studies have to be as similar as possible to the questions that they try to answer and the methods that they use. Considering the state of recent literature and our 
initial findings, we believe that a scoping review or narrative review that involves applying qualitative analytical techniques for synthesis could be an appropriate method for further reviews on European VET policy.

Fourth, reporting data allows a presentation of the findings of a review and the process of conducting it. It allows other researchers to follow the same steps and potentially achieve the same results. The literature review should not only follow a clear structure that ties studies to key topics, characteristics, and categories, but also indicates opportunities and directions for future research.

In this paper, we have documented an attempt to conduct a systematic literature review in the field of international VET research with a focus on European VET policy. We aimed to explore the extent to which this method is helpful in mapping the current state of research and systematizing knowledge in this field. Our experiences with attempting systematic literature reviews have confirmed that the basic stages of the review process appear to be useful. However, some modifications and extensions could significantly improve its value as a research method for future studies on VET policy, especially in Europe. Although our study highlights some challenges and future directions regarding applying the method proposed by Gessler and Siemer (2020), our pilot study also revealed some issues relating to the topics addressed in the individual articles reviewed. The core topics in the field of VET governance and European VET policy are governance mechanisms and the impact of European VET policy and related policies, including learning outcomes, qualifications frameworks, the Copenhagen process, and, to some extent, the Bologna process. Moreover, one of the core topics refers to the analysis of systems and structures of VET, including VET models and the collaboration and cooperation of stakeholders, and conceptualizing the coherence in VET and VET teachers and trainers. These are the starting points for mapping the field of European VET policy.

\section{Acknowledgement}

The authors acknowledge funding from the German Federal Ministry of Education and Research (project number: 01BF19001).

\section{References}

Ante, C. (2016). The Europeanisation of vocational education and training. Springer International Publishing.

Aveyard, H. (2010). Doing a literature review in health and social care: A practical guide. McGraw-Hill. Barabasch, A., \& Wolf, S. (2009). Die Policy-Praxis der Anderen. Policy-Transfer in der Bildungs- und Berufsbildungsforschung. Zeitschrift für internationale Bildungsforschung und Entwicklungspäd- 
agogik, 32(4), 22-27. https://www.pedocs.de/volltexte/2014/9594/pdf/ZEP_4_2009_Barabasch_ Wolf_Die_Policy_Praxis.pdf

Barabasch, A. (2010). Methodological and theoretical approaches to the study of governance and policy transfer in vocational education and training. Research in Comparative and International Education, 5(3), 224-36. https://doi.org/10.2304/rcie.2010.5.3.224

Bohlinger, S. (2012). Qualifications frameworks and learning outcomes: Challenges for Europe's lifelong learning area. Journal of Education and Work, 25(3), 279-297. https://doi.org/10.1080/13639 080.2012 .687571

Bohlinger, S. (2019). Ten years after. The "success story" of the European qualifications framework. Journal of Education and Work, 32(4), 393-406. https://doi.org/10.1080/13639080.2019.1646413

Bohlinger, S., Dang, T., \& Klatt, M. (2016). Education policy: Mapping the landscape and scope. Peter Lang.

Booth, A., Sutton, A., \& Papaioannou, D. (2016). Systematic approaches to a successful literature review. (2nd ed.). Sage.

Brockmann, M., Clarke, L., \& Winch, C. (2009). Competence and competency in the EQF and in European VET systems. Journal of European Industrial Training, 33, 8/9, 767-799. https://doi. org/10.1108/03090590910993634

Busemeyer, M. R., \& Trampusch, C. (2011). Comparative political science and the study of education. British Journal of Political Science, 41(2), 413-443. https://doi.org/10.1017/S0007123410000517

Caves, K. M., Baumann, S., \& Renold, U. (2019). Getting there from here: A literature review on vocational education and training reform implementation. Journal of Vocational Education \& Training, 73(1)1-32. https://doi.org/10.1080/13636820.2019.1698643

Clarke, L., Sahin-Dikmen, M., \& Winch, C. (2020). Overcoming diverse approaches to vocational education and training to combat climate change: The case of low energy construction in Europe. Oxford Review of Education, 46(5), 1-8. https://doi.org/10.1080/03054985.2020.1745167

Clarke, L., \& Winch, C. (2015). Have Anglo-Saxon concepts really influenced the development of European qualifications policy? Research in Comparative and International Education, 10(4), 593606. https://doi.org/10.1177/1745499915613247

Cort, P. (2010). Europeanisation and policy change in the Danish vocational education and training system. Research in Comparative and International Education, 5(3), 331-343. https://doi. org/10.2304/rcie.2010.5.3.331

de Paor, C. (2018). Supporting change in VET: Teachers' professional development and ECVET learner mobility. Empirical Research in Vocational Education and Training, 10(1), 1-13. https://doi. org/10.1186/s40461-017-0062-3

Deissinger, T. (2015). International education policy: Its influence on the conception of VET and the VET system in Germany. Research in Comparative and International Education, 10(4), 607-621. https://doi.org/10.1177/1745499915613248

Emmenegger, P., Graf, L., \& Trampusch, C. (2019). The governance of decentralised cooperation in collective training systems: A review and conceptualisation. Journal of Vocational Education and Training, 71(1), 21-45. https://doi.org/10.1080/13636820.2018.1498906

Euler, D. (2013). Germany's dual vocational training system: A model for other countries? Bertelsmann Stiftung. https://www.bertelsmann-stiftung.de/fileadmin/files/BSt/Publikationen/GrauePublikationen/GP_Germanys_dual_vocational_training_system.pdf 
Gessler, M., \& Siemer, C. (2020). Umbrella review: Methodological review of reviews published in peer-reviewed journals with a substantial focus on vocational education and training research. International Journal for Research in Vocational Education and Training, 7(1), 91-125. https://doi. org/10.13152/IJRVET.7.1.5

Greinert, W. D. (2004). European vocational training "systems"- some thoughts on the theoretical context of their historical development. European Journal of Vocational Training, 32, 18-25.

Grollmann, P., \& Ruth, K. (2006). The 'Europeanisation' of vocational education between formal policies and deliberative communication. Research in Comparative and International Education, 1(4), 366-380. https://doi.org/10.2304/rcie.2006.1.4.366

Hart, C. (2018). Doing a literature review: Release the Research Imagination. (2nd ed.). Sage.

Heikkinen, A. (2004). Models, paradigms or cultures of vocational education. European Journal of Vocational Training, 32, 32-44.

Kämäräinen, P. (2017). Learning from Europe and for Europe with David Raffe-insights into early years of European cooperation in vocational education and training research. Journal of Education and Work, 30(7), 750-757. https://doi.org/10.1080/13639080.2017.1380754

Li, J., \& Pilz, M. (2021). International transfer of vocational education and training: A literature review. Journal of Vocational Education \& Training, 1-34. https://doi.org/10.1080/13636820.2020.1847566

Loogma, K. (2016). Europeanization in VET policy as a process of reshaping the educational space. International Journal for Research in Vocational Education and Training, 3(1), 16-28. https://doi. org/10.13152/IJRVET.3.1.5

Markowitsch, J., \& Hefler, G. (2018). Staying in the loop: Formal feedback mechanisms connecting vocational training to the world of work in Europe. International Journal for Research in Vocational Education and Training, 5(4), 285-306. https://doi.org/10.13152/IJRVET.5.4.3

Masson, J. R. (2007). The contribution of European vocational training policy to reforms in the partner countries of the European Union. European Journal of Vocational Training, 41(2), 43-63.

Mewaldt, A. (2014). The market-oriented and integrative management model for successful internationalisation of vocational education and training services. Journal of Service Science, 7(1), 53-70.

Mikulec, B. (2019). Competences of adult education professionals in the European and Slovene context. Journal of Adult and ContinuingEducation, 25(1),25-44.https://doi.org/10.1177/1477971418805502

Misra, P. K. (2011). VET teachers in Europe: Policies, practices and challenges. Journal of Vocational Education and Training, 63(1), 27-45. https://doi.org/10.1080/13636820.2011.552732

Moher, D., Liberati, A., Tetzlaff, J., Altman, D. G., \& The PRISMA Group. (2009). Preferred reporting items for systematic reviews and meta-analyses: the PRISMA statement. PLoS Med, 6(7). https:// doi.org/10.1371/journal.pmed.1000097

Oliver, D. (2010). Complexity in vocational education and training governance. Research in Comparative and International Education, 5(3), 261-273. https://doi.org/10.2304/rcie.2010.5.3.261

Paulos, C. (2015). Qualification of adult educators in Europe: Insights from the Portuguese case. International Journal for Research in Vocational Education and Training, 2(1), 26-38. https://doi. org/10.13152/IJRVET.2.1.2

Pierre, P., \& Peters, B. G. (2005). Governing complex societies: Trajectories and scenarios. Palgrave Macmillan.

Pilz, M., Li, J., Canning, R., \& Minty, S. (2018). Modularisation approaches in initial vocational education: Evidence for policy convergence in Europe? Journal of Vocational Education and Training, 70(1), 1-26. https://doi.org/10.1080/13636820.2017.1392994 
Rauner, F., \& Wittig, W. (2010). Differences in the organisation of apprenticeship in Europe: Findings of a comparative evaluation study. Research in Comparative and International Education, 5(3), 237250. https://doi.org/10.2304/rcie.2010.5.3.237

Rein, V. (2017). Towards the compatibility of professional and scientific learning outcomes: Insights and options in the context of competence orientation. International Journal for Research in Vocational Education and Training, 4(4), 325-345. https://doi.org/10.13152/IJRVET.4.4.2

Roosmaa, E. L., Martma, L., \& Saar, E. (2019). Vocational upper-secondary education and participation in non-formal education: A comparison of European countries. International Journal of Lifelong Education, 38(3), 268-286. https://doi.org/10.1080/02601370.2019.1586779

Ryan, C., Bergin, M., Titze, S., Ruf, W., Kunz, S., \& Wells, J. S. (2018). ECVET and ECTS credit equivalency in higher education-A bridge too far? European Journal of Education, 53(4), 600-610. https://doi.org/10.1111/ejed.12297

Šćepanović, V., \& Artiles, A. M. (2020). Dual training in Europe: A policy fad or a policy turn? Transfer: European Review of Labour and Research, 26(1), 15-26. https://doi.org/10.1177/1024258919898317

Smith, P. J., \& Smith, S. N. (1999). The Internationalisation of Vocational Education and Training. Review of Research. National Centre for Vocational Education Research.

Souto-Otero, M., \& Ure, O. B. (2012). The coherence of vocational education and training in Norway and Spain: National traditions and the reshaping of VET governance in hybrid VET systems. Compare: A Journal of Comparative and International Education, 42(1), 91-111. https://doi.org/10.108 $0 / 03057925.2011 .628836$

Trampusch, C. (2009). Europeanization and institutional change in vocational education and training in Austria and Germany. Governance, 22(3), 369-395. https://doi.org/10.1111/j.14680491.2009.01444.x

Tran, L. T. (2013). Internationalisation of vocational education and training: An adapting curve for teachers and learners. Journal of Studies in International Education, 17(4), 492-507. https://doi. org/10.1177/1028315312469987

Ure, O. B. (2015). Governance for learning outcomes in European policy-making. Qualification frameworks pushed through the open method of coordination. International Journal for Research in Vocational Education and Training, 2(4), 268-283. https://doi.org/10.13152/IJRVET.2.4.2

van Houten, M. M. (2018). Vocational education and the binary higher education system in the Netherlands: Higher education symbiosis or vocational education dichotomy? Journal of Vocational Education \& Training, 70(1), 130-147. https://doi.org/10.1080/13636820.2017.1394359

Viertel, E. (2010). Vocational education for sustainable development: An obligation for the European Training Foundation. European Journal of Education, 45(2), 217-235. https://doi.org/10.1111/ j.1465-3435.2010.01426.x

Walkenhorst, H. (2005). Europeanisation of the German education system. German Politics, 14(4), 470-486. https://doi.org/10.1080/09644000500340644

Winterton, J. (2007). Building social dialogue over training and learning: European and national developments. European Journal of Industrial Relations, 13(3), 281-300. https://doi. org/10.1177/0959680107081742 


\section{Biographical Notes}

Ianina Scheuch is a research assistant at the Chair of Adult Education at the TU Dresden in Germany. Her research interests focus on business education, vocational education and training, and international comparative education.

Sandra Bohlinger is Full Professor of Adult Education at the TU Dresden in Germany. Her research interests include vocational education and training, and comparative education.

Anne Bieß is a research assistant at the Chair of Adult Education at the TU Dresden in Germany. Her research interests focus on vocational education and training, comparative education, adult education, and further education.

Hoang Long Nguyen is a research assistant at the Chair of Adult Education at the TU Dresden in Germany. His research interests focus on occupational social work, vocational education and training, and adult education.

\section{Appendix}

\section{Included Papers}

\begin{tabular}{|c|c|c|c|c|c|}
\hline \# & Name & Title & Year & Journal & Category \\
\hline 1 & Bohlinger, S. & $\begin{array}{l}\text { Qualifications frameworks and learning } \\
\text { outcomes: Challenges for Europe's } \\
\text { lifelong learning area }\end{array}$ & 2012 & $\begin{array}{l}\text { Journal of Education } \\
\text { and Work }\end{array}$ & $\begin{array}{l}\text { Governance in } \\
\text { European VET policy } \\
\text { at the EU-system level }\end{array}$ \\
\hline 2 & $\begin{array}{l}\text { Clarke, L., } \\
\text { Sahin-Dikmen, } \\
\text { M., \& Winch, C. }\end{array}$ & $\begin{array}{l}\text { Overcoming diverse approaches to } \\
\text { vocational education and training to } \\
\text { combat climate change: The case of low } \\
\text { energy construction in Europe }\end{array}$ & 2020 & $\begin{array}{l}\text { Oxford Review of } \\
\text { Education }\end{array}$ & $\begin{array}{l}\text { European VET policy } \\
\text { and cross-country } \\
\text { comparison in the EU }\end{array}$ \\
\hline 3 & $\begin{array}{l}\text { Clarke, L., \& } \\
\text { Winch, C. }\end{array}$ & $\begin{array}{l}\text { Have Anglo-Saxon concepts really } \\
\text { influenced the development of Euro- } \\
\text { pean qualifications policy? }\end{array}$ & 2015 & $\begin{array}{l}\text { Research in } \\
\text { Comparative \& } \\
\text { International } \\
\text { Education }\end{array}$ & $\begin{array}{l}\text { Governance in } \\
\text { European VET policy } \\
\text { at the EU-system level }\end{array}$ \\
\hline 4 & Cort, P. & $\begin{array}{l}\text { Europeanisation and policy change in } \\
\text { the Danish vocational education and } \\
\text { training system }\end{array}$ & 2010 & $\begin{array}{l}\text { Research in } \\
\text { Comparative and } \\
\text { International } \\
\text { Education }\end{array}$ & $\begin{array}{l}\text { European VET policy } \\
\text { implementation at } \\
\text { national level }\end{array}$ \\
\hline 5 & de Paor, C. & $\begin{array}{l}\text { Supporting change in VET: Teachers' } \\
\text { professional development and ECVET } \\
\text { learner mobility }\end{array}$ & 2018 & $\begin{array}{l}\text { Empirical Research in } \\
\text { Vocational Education } \\
\text { and Training }\end{array}$ & $\begin{array}{l}\text { European VET policy } \\
\text { implementation at } \\
\text { national level }\end{array}$ \\
\hline 6 & Deissinger, $\mathrm{T}$. & $\begin{array}{l}\text { International education policy: Its } \\
\text { influence on the conception of VET } \\
\text { and the VET system in Germany }\end{array}$ & 2015 & $\begin{array}{l}\text { Research in } \\
\text { Comparative and } \\
\text { International } \\
\text { Education }\end{array}$ & $\begin{array}{l}\text { European VET policy } \\
\text { implementation at } \\
\text { national level }\end{array}$ \\
\hline
\end{tabular}




\begin{tabular}{|c|c|c|c|c|c|}
\hline 7 & $\begin{array}{l}\text { Emmenegger, } \\
\text { P., Graf, L., \& } \\
\text { Trampusch, C. }\end{array}$ & $\begin{array}{l}\text { The governance of decentralised } \\
\text { cooperation in collective training } \\
\text { systems: A review and } \\
\text { conceptualisation }\end{array}$ & 2019 & $\begin{array}{l}\text { Journal of Vocational } \\
\text { Education \& Training }\end{array}$ & $\begin{array}{l}\text { Governance in } \\
\text { European VET policy } \\
\text { at the EU-system level }\end{array}$ \\
\hline 8 & Greinert, W. D.* & $\begin{array}{l}\text { European vocational training } \\
\text { "systems"- Some thoughts on the } \\
\text { theoretical context of their historical } \\
\text { development }\end{array}$ & 2004 & $\begin{array}{l}\text { European Journal of } \\
\text { Vocational Training }\end{array}$ & $\begin{array}{l}\text { Governance in } \\
\text { European VET policy } \\
\text { at the EU-system level }\end{array}$ \\
\hline 9 & $\begin{array}{l}\text { Grollmann, P., } \\
\text { \& Ruth, K. }\end{array}$ & $\begin{array}{l}\text { The 'Europeanisation' of vocational } \\
\text { education between formal policies and } \\
\text { deliberative communication }\end{array}$ & 2006 & $\begin{array}{l}\text { Research in } \\
\text { Comparative \& } \\
\text { International } \\
\text { Education }\end{array}$ & $\begin{array}{l}\text { Governance in } \\
\text { European VET policy } \\
\text { at the EU-system level }\end{array}$ \\
\hline 10 & Heikkinen, A.* & $\begin{array}{l}\text { Models, paradigms or cultures of } \\
\text { vocational education }\end{array}$ & 2004 & $\begin{array}{l}\text { European Journal of } \\
\text { Vocational Training }\end{array}$ & $\begin{array}{l}\text { European VET policy } \\
\text { and cross-country } \\
\text { comparison in the EU }\end{array}$ \\
\hline 11 & Kämäräinen, P. & $\begin{array}{l}\text { Learning from Europe and for Europe } \\
\text { with David Raffe - insights into early } \\
\text { years of European cooperation in } \\
\text { vocational education and training } \\
\text { research }\end{array}$ & 2017 & $\begin{array}{l}\text { Journal of Education } \\
\text { and Work }\end{array}$ & $\begin{array}{l}\text { Governance in } \\
\text { European VET policy } \\
\text { at the EU-system level }\end{array}$ \\
\hline 12 & Loogma, K. & $\begin{array}{l}\text { Europeanization in VET policy as a } \\
\text { process of reshaping the educational } \\
\text { space }\end{array}$ & 2016 & $\begin{array}{l}\text { International Journal } \\
\text { for Research in } \\
\text { Vocational Education } \\
\text { and Training }\end{array}$ & $\begin{array}{l}\text { European VET policy } \\
\text { implementation at } \\
\text { national level }\end{array}$ \\
\hline 13 & $\begin{array}{l}\text { Markowitsch, J., } \\
\text { \& Hefler, G. }\end{array}$ & $\begin{array}{l}\text { Staying in the loop: Formal feedback } \\
\text { mechanisms connecting vocational } \\
\text { training to the world of work in Europe }\end{array}$ & 2018 & $\begin{array}{l}\text { International Journal } \\
\text { of Research in } \\
\text { Vocational Education } \\
\text { and Training } \\
\end{array}$ & $\begin{array}{l}\text { European VET policy } \\
\text { and cross-country } \\
\text { comparison in the EU }\end{array}$ \\
\hline 14 & Masson, J. R. & $\begin{array}{l}\text { The Contribution of European } \\
\text { vocational training policy to reforms in } \\
\text { the partner countries of the European } \\
\text { Union }\end{array}$ & 2007 & $\begin{array}{l}\text { European Journal of } \\
\text { Vocational Training }\end{array}$ & $\begin{array}{l}\text { European VET policy } \\
\text { and cross-country } \\
\text { comparison in the EU }\end{array}$ \\
\hline 15 & Mikulec, B. & $\begin{array}{l}\text { Competences of adult education } \\
\text { professionals in the European and } \\
\text { Slovene context }\end{array}$ & 2019 & $\begin{array}{l}\text { Journal of Adult and } \\
\text { Continuing Education }\end{array}$ & $\begin{array}{l}\text { European VET policy } \\
\text { implementation at } \\
\text { national level }\end{array}$ \\
\hline 16 & Misra, P. K. & $\begin{array}{l}\text { VET teachers in Europe: Policies, } \\
\text { practices and challenges }\end{array}$ & 2011 & $\begin{array}{l}\text { Journal of Vocational } \\
\text { Education \& Training }\end{array}$ & $\begin{array}{l}\text { European VET policy } \\
\text { and cross-country } \\
\text { comparison in the EU }\end{array}$ \\
\hline 17 & Oliver, D. & $\begin{array}{l}\text { Complexity in vocational education } \\
\text { and training governance }\end{array}$ & 2010 & $\begin{array}{l}\text { Research in } \\
\text { Comparative and } \\
\text { International } \\
\text { Education }\end{array}$ & $\begin{array}{l}\text { Governance in Euro- } \\
\text { pean VET policy at the } \\
\text { EU-system level }\end{array}$ \\
\hline 18 & Paulos, C. & $\begin{array}{l}\text { Qualification of adult educators in Eu- } \\
\text { rope: Insights from the Portuguese case }\end{array}$ & 2015 & $\begin{array}{l}\text { International Journal } \\
\text { of Research in Voca- } \\
\text { tional Education and } \\
\text { Training }\end{array}$ & $\begin{array}{l}\text { European VET policy } \\
\text { implementation at } \\
\text { national level }\end{array}$ \\
\hline 19 & $\begin{array}{l}\text { Pilz, M., Li, J., } \\
\text { Canning, R., \& } \\
\text { Minty, S. }\end{array}$ & $\begin{array}{l}\text { Modularisation approaches in Initial } \\
\text { Vocational Education: Evidence for } \\
\text { policy convergence in Europe? }\end{array}$ & 2018 & $\begin{array}{l}\text { Journal of Vocational } \\
\text { Education \& Training }\end{array}$ & $\begin{array}{l}\text { European VET policy } \\
\text { and cross-country } \\
\text { comparison in the EU }\end{array}$ \\
\hline 20 & $\begin{array}{l}\text { Rauner, F., \& } \\
\text { Wittig, W. }\end{array}$ & $\begin{array}{l}\text { Differences in the organisation of } \\
\text { apprenticeship in Europe: Findings of a } \\
\text { comparative evaluation study }\end{array}$ & 2010 & $\begin{array}{l}\text { Research in } \\
\text { Comparative and In- } \\
\text { ternational Education }\end{array}$ & $\begin{array}{l}\text { Governance in Euro- } \\
\text { pean VET policy at the } \\
\text { EU-system level }\end{array}$ \\
\hline
\end{tabular}




\begin{tabular}{|c|c|c|c|c|c|}
\hline 21 & Rein, V. & $\begin{array}{l}\text { Towards the compatibility of } \\
\text { professional and scientific learning } \\
\text { outcomes: Insights and options in the } \\
\text { context of competence orientation }\end{array}$ & 2017 & $\begin{array}{l}\text { International Journal } \\
\text { of Research in } \\
\text { Vocational Education } \\
\text { and Training }\end{array}$ & $\begin{array}{l}\text { European VET policy } \\
\text { implementation at } \\
\text { national level }\end{array}$ \\
\hline 22 & $\begin{array}{l}\text { Roosmaa, E. L., } \\
\text { Martma, L., \& } \\
\text { Saar, E. }\end{array}$ & $\begin{array}{l}\text { Vocational upper-secondary } \\
\text { education and participation in non- } \\
\text { formal education: a comparison of } \\
\text { European countries }\end{array}$ & 2019 & $\begin{array}{l}\text { International Journal } \\
\text { of Lifelong Education }\end{array}$ & $\begin{array}{l}\text { European VET policy } \\
\text { and cross-country } \\
\text { comparison in the EU }\end{array}$ \\
\hline 23 & $\begin{array}{l}\text { Ryan, C., } \\
\text { Bergin, M., } \\
\text { Titze, S., Ruf, } \\
\text { W., Kunz, S., \& } \\
\text { Wells, J. S. }\end{array}$ & $\begin{array}{l}\text { ECVET and ECTS credit equivalency } \\
\text { in higher education-A bridge too far? }\end{array}$ & 2018 & $\begin{array}{l}\text { European Journal of } \\
\text { Education }\end{array}$ & $\begin{array}{l}\text { Governance in } \\
\text { European VET policy } \\
\text { at the EU-system level }\end{array}$ \\
\hline 24 & $\begin{array}{l}\text { Scepanovi, V., \& } \\
\text { Artiles, A. M.** }\end{array}$ & $\begin{array}{l}\text { Dual training in Europe: A policy fad } \\
\text { or a policy turn? }\end{array}$ & 2020 & $\begin{array}{l}\text { Transfer, The } \\
\text { European Review of } \\
\text { Labour and Research }\end{array}$ & $\begin{array}{l}\text { Governance in } \\
\text { European VET policy } \\
\text { at the EU-system level }\end{array}$ \\
\hline 25 & $\begin{array}{l}\text { Souto-Otero, } \\
\text { M., \& Ure, O. B. }\end{array}$ & $\begin{array}{l}\text { The coherence of vocational education } \\
\text { and training in Norway and Spain: } \\
\text { National traditions and the reshaping } \\
\text { of VET governance in hybrid VET } \\
\text { systems }\end{array}$ & 2012 & $\begin{array}{l}\text { Compare: A Journal of } \\
\text { Comparative and } \\
\text { International } \\
\text { Education }\end{array}$ & $\begin{array}{l}\text { European VET policy } \\
\text { and cross-country } \\
\text { comparison in the EU }\end{array}$ \\
\hline 26 & Trampusch, C. & $\begin{array}{l}\text { Europeanization and institutional } \\
\text { change in vocational education and } \\
\text { training in Austria and Germany }\end{array}$ & 2009 & $\begin{array}{l}\text { Governance: An } \\
\text { International Journal } \\
\text { of Policy, } \\
\text { Administration, and } \\
\text { Institutions }\end{array}$ & $\begin{array}{l}\text { European VET policy } \\
\text { and cross-country } \\
\text { comparison in the EU }\end{array}$ \\
\hline 27 & Ure, O. B. & $\begin{array}{l}\text { Governance for learning outcomes in } \\
\text { European policy-making: Qualification } \\
\text { frameworks pushed through the open } \\
\text { method of coordination }\end{array}$ & 2015 & $\begin{array}{l}\text { International Journal } \\
\text { for Research in } \\
\text { Vocational Education } \\
\text { and Training }\end{array}$ & $\begin{array}{l}\text { Governance in } \\
\text { European VET policy } \\
\text { at the EU-system level }\end{array}$ \\
\hline 28 & $\begin{array}{l}\text { van Houten, } \\
\text { M. M. }\end{array}$ & $\begin{array}{l}\text { Vocational education and the binary } \\
\text { higher education system in the } \\
\text { Netherlands: Higher education } \\
\text { symbiosis or vocational education } \\
\text { dichotomy? }\end{array}$ & 2018 & $\begin{array}{l}\text { Journal of } \\
\text { Vocational Education } \\
\text { and Training }\end{array}$ & $\begin{array}{l}\text { European VET policy } \\
\text { implementation at } \\
\text { national level }\end{array}$ \\
\hline 29 & Viertel, E. & $\begin{array}{l}\text { Vocational education for sustainable } \\
\text { development: An obligation for the } \\
\text { European Training Foundation }\end{array}$ & 2010 & $\begin{array}{l}\text { European Journal of } \\
\text { Education }\end{array}$ & $\begin{array}{l}\text { Governance in } \\
\text { European VET policy } \\
\text { at the EU-system level }\end{array}$ \\
\hline 30 & Winterton, J. & $\begin{array}{l}\text { Building social dialogue over training } \\
\text { and learning: European and national } \\
\text { developments }\end{array}$ & 2007 & $\begin{array}{l}\text { European Journal of } \\
\text { Industrial Relations }\end{array}$ & $\begin{array}{l}\text { European VET policy } \\
\text { and cross-country } \\
\text { comparison in the EU }\end{array}$ \\
\hline
\end{tabular}

